\title{
Photosynthesis of Birch Genotypes (Betula L.) Under Varied Irradiance and $\mathrm{CO}_{2}$ Concentration
}

\author{
Mengmeng $\mathbf{G u}^{1,4,5}$ \\ PTSC 316, Department of Horticulture, University of Arkansas, Fayetteville, \\ AR 72701
}

\author{
James A. Robbins ${ }^{2}$ \\ Cooperative Extension Service, P.O Box 391, University of Arkansas, Little \\ Rock, AR 72203
}

Curt R. Rom ${ }^{3}$

Department of Horticulture, PTSC 316, University of Arkansas, Fayetteville, AR 72701

\author{
Hyun-Sug Choi ${ }^{1}$ \\ PTSC 316, Department of Horticulture, University of Arkansas, Fayetteville, \\ AR 72701
}

Additional index words. photosynthetic photon flux density, net assimilation rate, quantum yield, carboxylation efficiency

Abstract. Net $\mathrm{CO}_{2}$ assimilation (A) of four birch genotypes (Betula nigra L. 'Cully', B. papyrifera Marsh., B. alleghaniensis Britton, and B. davurica Pall.) was studied under varied photosynthetic photon flux density (PPFD) and $\mathrm{CO}_{2}$ concentrations $\left(\mathrm{CO}_{2}\right)$ as indicators to study their shade tolerance and potential for growth enhancement using $\mathrm{CO}_{2}$ enrichment. Effect of water-deficit stress on assimilation under varied PPFD and $\left(\mathrm{CO}_{2}\right)$ was also investigated for $B$. papyrifera. The light saturation point at $350 \mathrm{ppm}$ $\left(\mathrm{CO}_{2}\right)$ for the four genotypes varied from 743 to $1576 \mu \mathrm{mol} \cdot \mathrm{m}^{-2} \cdot \mathrm{s}^{-1}$ photon, and the $\mathrm{CO}_{2}$ saturation point at $1300 \mu \mathrm{mol} \cdot \mathrm{m}^{-2} \cdot \mathrm{s}^{-1}$ photon varied from 767 to $1251 \mathrm{ppm}$. Light-saturated assimilation ranged from $10.4 \mu \mathrm{mol} \cdot \mathrm{m}^{-2} \cdot \mathrm{s}^{-1}$ in $B$. alleghaniensis to 13.1 $\mu \mathrm{mol} \cdot \mathrm{m}^{-2} \cdot \mathrm{s}^{-1}$ in B. davurica. $\mathrm{CO}_{2}$-saturated A ranged from $18.8 \mu \mathrm{mol} \cdot \mathrm{m}^{-2} \cdot \mathrm{s}^{-1}$ in $\mathrm{B}$. nigra 'Cully' to $33.3 \mu \mathrm{mol} \cdot \mathrm{m}^{-2} \cdot \mathrm{s}^{-1}$ in $B$. davurica. Water-deficit stress significantly reduced the light saturation point to $366 \mu \mathrm{mol}$ photon $\mathrm{m}^{-2} \cdot \mathrm{s}^{-1}$ but increased the $\mathrm{CO}_{2}$ saturation point in B. papyrifera. Carboxylation efficiency was reduced $46 \%$ and quantum efficiency was reduced $30 \%$ by water-deficit stress in $B$. papyrifera.

There are various light conditions in landscape situations, i.e., full sun, partial sun, or shade, and plants have different requirements for light. Photosynthetically active irradiance is an important ecological factor on which all photoautotrophic plants depend (Lambers et al., 1998). Photosynthesis is highly correlated with photosynthetic photon flux density (PPFD), and thus net carbon gain and biomass production, if other factors are optimal such as water and nutrient supply. Low PPFD could limit the photosynthesis rate in sun plants and therefore limit plant growth. High PPFD may result in photoinhibition under certain growing conditions when excess

\footnotetext{
Received for publication 14 May 2007. Accepted for publication 2 Oct. 2007.

${ }^{1}$ Graduate assistant.

${ }^{2}$ Professor-Extension specialist.

${ }^{3}$ Professor.

${ }^{4}$ Current address: Mississippi State University, Plant and Soil Sciences, Department of Plant Soil Sciences, Box 9555, Mississippi State, MS 39762. ${ }^{5}$ To whom reprint requests should be addressed; e-mailmgu@pss.msstate.edu
}

energy could not be dissipated through photochemistry (Lambers et al., 1998). Excess excitation energy may cause damage to the photosynthetic apparatus when it exceeds the capacity of other dissipation mechanism. Ambient $\mathrm{CO}_{2}$ concentration $\left(\mathrm{CO}_{2}\right)$ is a limiting factor to net $\mathrm{CO}_{2}$ assimilation (A) in $\mathrm{C}_{3}$ plants (Lambers et al., 1998). Thus, increasing $\left(\mathrm{CO}_{2}\right)$ could potentially enhance photosynthesis and growth in $\mathrm{C}_{3}$ plants. Supplemental $\mathrm{CO}_{2}$ has been applied to improve production of vegetables or fruits in controlled environments (Edwards et al., 2004; Gao et al., 2004; Wei et al., 2004). Birch trees (Betula L.) are normally produced outdoors; however, vegetative propagation of some selections might benefit from supplemental $\mathrm{CO}_{2}$ application in a greenhouse. No previous research has been conducted on $\mathrm{CO}_{2}$ enrichment during nursery production of birch.

Light and $\mathrm{CO}_{2}$ responses are commonly used to explore the photosynthesis mechanism of plants. Single-leaf photosynthesis measurement (Peng and Krieg, 1992) provides a good estimate of a plant's maximum photosynthetic potential, although intracanopy shading may affect the accuracy of the single leaf as an indicator of the whole-plant photosynthesis responses (Makino and Mae, 1999).

Birch consists of $\approx 50$ deciduous species throughout the northern hemisphere (Krussmann, 1984). Birch trees are popular landscape trees for the attractive white bark, fall foliage, or pendulous catkins. Most birch trees are pioneer species in their natural habitat (Atkinson, 1992; Kobe and Coates, 1997; O'Hanlon-Manners and Kotanen, 2004) and rarely exist in the inner canopy of forests, which indicates that they may not be shade-tolerant. Previous research $(\mathrm{Gu}$ et al., 2003) suggested that there was a range of A under identical PPFD within the Betula genus. A better understanding of shade intolerance would contribute in selection and improvement among the birch trees for varied light conditions in the landscape. Although B. papyrifera was found to be the most shadeintolerant compared with other forest species based on models of sampling mortality in existing woods (Kobe and Coates, 1997), applying such an approach to Betula species in the landscape would not be feasible simply because of their diverse provenance. Four birch genotypes from diverse origins were selected for the experiment $(B$. nigra L. 'Cully' from the eastern United States, $B$. papyrifera Marsh. from North America, $B$. alleghaniensis Britton from eastern North America, and B. davurica Pall. from northeast China), and B. papyrifera was selected to study the water status effect on light and $\mathrm{CO}_{2}$ responses resulting from its popularity in the landscape.

There have been no previous reports on light response or $\mathrm{CO}_{2}$ response of birch genotypes. The objectives of this research were to: 1) compare light and $\mathrm{CO}_{2}$ responses in the four birch genotypes; and 2) evaluate water status effect on light and $\mathrm{CO}_{2}$ responses in $B$. papyrifera. The hypotheses were that there is a difference in light and $\mathrm{CO}_{2}$ responses among the four birch genotypes and that water deficit could affect quantum efficiency and carboxylation efficiency in $B$. papyrifera, which could serve as a basis for recommending birch genotypes for landscapes with various light conditions, plant water status management in the landscape, and $\mathrm{CO}_{2}$ enrichment for birch production under controlled environments.

\section{Materials and Methods}

\section{Plant material and growing conditions}

Four birch genotypes (B. nigra 'Cully', $B$. papyrifera, $B$. alleghaniensis, and $B$. davurica) obtained as rooted cuttings or bare-root plants were potted in 3.8-L pots with SunGro SB 300 Universal Mix (Pine Bluff, AR) in Winter 2003 and placed in an outdoor lathe house at the Arkansas Agriculture Research and Extension Center at Fayetteville.

The container plants were transported to the greenhouse at the Rosen Alternative Pest Control Center in June 2004. Five grams of Osmocote ${ }^{\circledR} 18 \mathrm{~N}-2.6 \mathrm{P}-9.9 \mathrm{~K}$ were topdressapplied to each container. Plants were grown in the greenhouse with ambient $\left(\mathrm{CO}_{2}\right)$ and 
the supplemental metal halide high-intensity discharge lights, which were automatically turned on when the ambient light level decreased to below 60 Klux. Photosynthetic photon flux density was $\approx 750 \mu \mathrm{mol} \cdot \mathrm{m}^{-2} \cdot \mathrm{s}^{-1}$ photon at the upper canopy level when the supplemental lights were turned on. The greenhouse conditions were programmed at day/night temperatures of $25 \pm 2 / 20 \pm 2{ }^{\circ} \mathrm{C}$ and relative humidity of $50 \%$. Plants were trained to a single shoot and the height of the plants was $\approx 1.2 \mathrm{~m}$ before the initiation of the experiments.

\section{Expt. 1: light response (A/PPFD) of four} well-watered birch genotypes

Six trees of similar size were selected for each genotype and the experiment was conducted on the 8, 9, and 10 Sept. 2004. Gas exchange measurements were taken between $900 \mathrm{HR}$ and $1330 \mathrm{HR}$ (CDST; 1 to $4.5 \mathrm{~h}$ after sunrise) using a portable gas exchange analyzer (CIRAS-1 Analyzer; PP Systems, Haverhill, MA). The cuvette conditions were set at $25^{\circ} \mathrm{C}$ and $350 \mathrm{ppm}\left(\mathrm{CO}_{2}\right)$. The air in the cuvette was maintained at $\approx 70 \%$ relative humidity to minimize stomatal heterogeneity (Griffin et al., 2004b).

Measurements were taken on a $2.5-\mathrm{cm}^{2}$ section on the center of the fifth unfolded leaf from the apex of each tree as described by Pettersson and McDonald (1992), and the midvein was avoided from being included in the cuvette. One measurement was taken on each leaf to get one data point in both light and $\mathrm{CO}_{2}$ responses. Dark respiration $\left(\mathrm{R}_{\mathrm{d}}\right)$ was recorded when the light supply unit was detached from the cuvette head and aluminum foil was used to cover the cuvette to avoid scattered radiation on the leaf (PPFD $=$ $0 \mu \mathrm{mol} \cdot \mathrm{m}^{-2} \cdot \mathrm{s}^{-1}$ photon). The light supply unit was replaced back to the cuvette head and irradiance increased incrementally $(25,50$, $100,250,500,750,1000,1250,1500,1750$, $2000 \mu \mathrm{mol} \cdot \mathrm{m}^{-2} \cdot \mathrm{s}^{-1}$ photon). After an $\approx 15-\mathrm{min}$ acclimation period, A was recorded at each light level and fitted to the model equation

$$
A=\left[\Phi \times P P F D+A \max -\sqrt{(\Phi \times P P F D+A \max )^{2}-4 \Phi \times P P F D \times k \times A \max }\right] /(2 k)-R_{d}
$$

as given by Lambers et al. (1998) in which $\mathrm{A}$ is the net $\mathrm{CO}_{2}$ assimilation rate, $\Phi$ is the quantum efficiency, PPFD is the incident irradiance, Amax is the lightsaturated rate of gross $\mathrm{CO}_{2}$ assimilation (light-saturated net $\mathrm{CO}_{2}$ assimilation plus $\mathrm{R}_{\mathrm{d}}$ ) at infinitely high irradiance, and $\mathrm{k}$ is the curvature factor describing the convexity of the curve, which can vary between 0 and 1 . When $\mathrm{k}$ is close to 1 , the curve changes directly from the initial line determined by $\Phi$ to a plateau (called Blackman type) determined by Amax and $\mathrm{R}_{\mathrm{d}}$ (Leverenz, 1987; Ogren, 1993). When $\mathrm{k}$ is close to 0 , the curve is a rectangular hyperbola (Leverenz, 1987).

Light compensation point at ambient $\left(\mathrm{CO}_{2}\right)(350 \mathrm{ppm})$, referred to as $\mathrm{PPFD}_{\text {comp }}$, was calculated when $A$ was equal to 0 . The value of PPFD sat at ambient $\left(\mathrm{CO}_{2}\right)$ was cal-
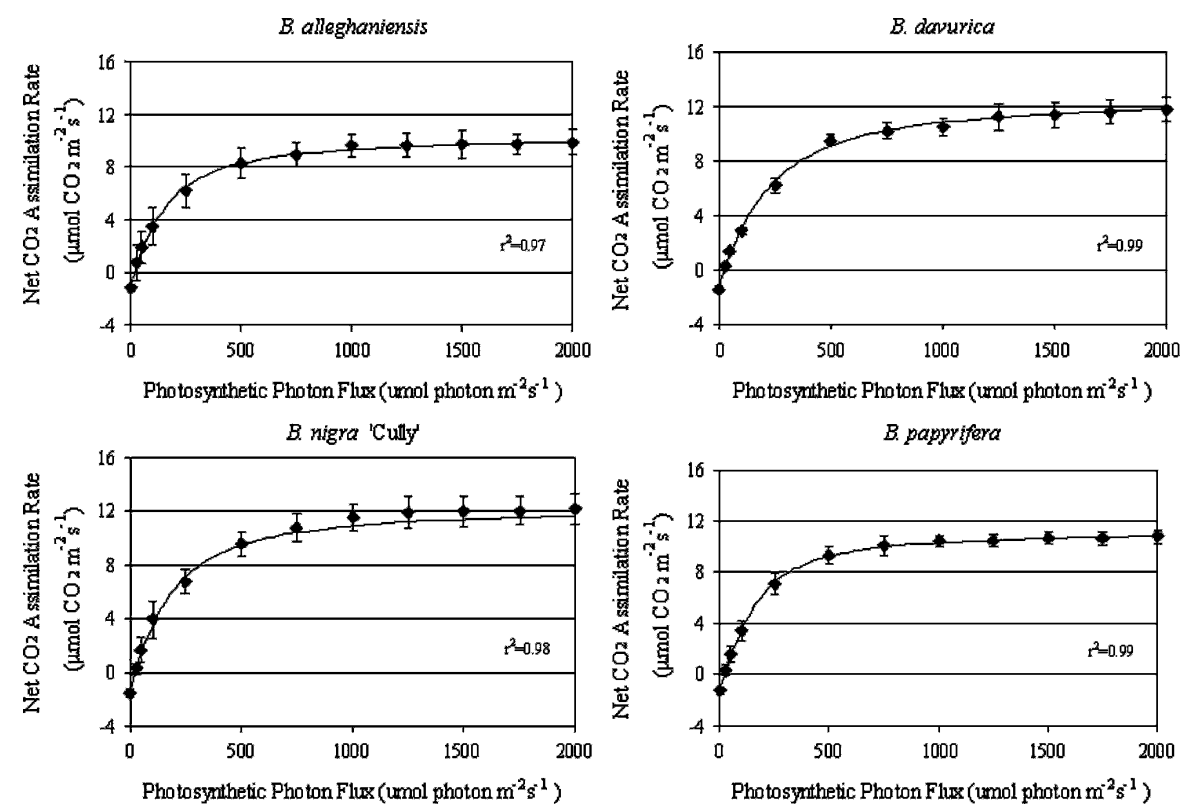

Fig. 1. Net $\mathrm{CO}_{2}$ assimilation rate (A) in response to varied photosynthetic photon flux density (PPFD) of four birch genotypes. The cuvette conditions were set at $25^{\circ} \mathrm{C}, 70 \%$ relative humidity, and $350 \mathrm{ppm}$ $\left(\mathrm{CO}_{2}\right)$. Diamond symbols are means of six plants. Vertical bars $( \pm \mathrm{SE})$ were shown if greater than the symbol size. Curves were predicted values from the following equations generated by SAS PROC NLIN from the measured data. B. alleghaniensis: $A=[0.068 \times$ PPFD $+11.99-$ $\left.\sqrt{(0.068 \times P P F D+11.99)^{2}-0.75 \times P P F D}\right] / 1.00-1.05 ;$ B. davurica: $\mathrm{A}=[0.053 \times \mathrm{PPFD}+13.20$ $\left.-\sqrt{(0.053 \times P P F D+13.20)^{2}-1.40 \times P P F D}\right] / 1.01-1.40 ;$ B. nigra 'Cully': $\mathrm{A}=[0.060 \times$ PPFD + $\left.12.80-\sqrt{(0.060 \times P P F D+12.80)^{2}-1.55 \times P P F D}\right] / 1.00-1.09 ;$ B. papyrifera: $\mathrm{A}=[0.052 \times \mathrm{PPFD}$ $\left.+12.14-\sqrt{(0.052 \times P P F D+12.14)^{2}-1.86 \times P P F D}\right] / 1.48-1.10$.

culated as the PPFD associated with $90 \%$ of Amax like by Jurik et al. (1988). Lightsaturated $\mathrm{A}$ at ambient $\left(\mathrm{CO}_{2}\right)$ was calculated when PPFD was equal to PPFD sat $_{\text {. The PPFD }}$ associated with a 50\% reduction in Amax $\left(\right.$ PPFD $\left._{50 \%}\right)$ was also calculated.

\section{Expt. 2: $\mathrm{CO}_{2}$ response $\left[\mathrm{A} /\left(\mathrm{CO}_{2}\right)\right]$ of four well-watered birch genotypes}

$\mathrm{A} /\left(\mathrm{CO}_{2}\right)$ of each genotype was measured on the same fifth leaf between $900 \mathrm{HR}$ and 1330 HR (CDST; 1 to $4.5 \mathrm{~h}$ after sunrise) on

11, 12, and 13 Sept. 2004. The cuvette condition started as $0 \mathrm{ppm}\left(\mathrm{CO}_{2}\right), 25{ }^{\circ} \mathrm{C}, 70 \%$ relative humidity, and $1300 \mu \mathrm{mol} \cdot \mathrm{m}^{-2} \cdot \mathrm{s}^{-1}$ photon PPFD. This level of PPFD was close to the PPFD $_{\text {sat }}$ estimated from A/PPFD for the four birch genotypes. Pettersson and McDonald (1992) applied $600 \mu \mathrm{mol} \cdot \mathrm{m}^{-2} \cdot \mathrm{s}^{-1}$ photon PPFD on B. pendula in a similar study, which was not adopted in this study because it was significantly lower than the sunlight level on a sunny day or the $\mathrm{PPFD}_{\text {sat }}$ estimated in Expt. 1. $\left(\mathrm{CO}_{2}\right)$ was incrementally increased from 0 to $1100 \mathrm{ppm}(50$, $100,200,300,400,500,600,700,800,900$, 1000,1100 ppm). Net $\mathrm{CO}_{2}$ assimilation was recorded after an $\approx 15-\mathrm{min}$ acclimation at each $\left(\mathrm{CO}_{2}\right)$ level. Data were fitted to the negative exponential model adjusted from Reid and Fiscus (1998): $A=a\left(1-e^{-b C a}\right)+c$, where $a$ is the potential assimilation capacity, $b$ is the initial slope or carboxylation efficiency, $\mathrm{Ca}$ is the ambient $\mathrm{CO}_{2}$ concentration, and $c$ is the intercept on the ordinate [A at the level when $\left.\left(\mathrm{CO}_{2}\right)=0 \mathrm{ppm}\right]$.

$\mathrm{CO}_{2}$ compensation point at $1300 \mu \mathrm{mol}$ photon $\mathrm{m}^{-2} \cdot \mathrm{s}^{-1} \mathrm{PPFD}$, referred to as $\left(\mathrm{CO}_{2}\right)_{\mathrm{comp}}$, was calculated when $\mathrm{A}$ was equal to 0 . The value of $\left(\mathrm{CO}_{2}\right)_{\text {sat }}$ at $1300 \mu \mathrm{mol}$ photon $\mathrm{m}^{-2} \cdot \mathrm{s}^{-1}$ PPFD was calculated in a similar way as PPFD $_{\text {sat }}\left[\left(\mathrm{CO}_{2}\right)\right.$ associated with $90 \%$ of $\left.a\right]$ $\left(\mathrm{CO}_{2}\right)$-saturated $\mathrm{A}$ at $1300 \mu \mathrm{mol} \cdot \mathrm{m}^{-2} \cdot \mathrm{s}^{-1}$ photon PPFD was calculated when $\left(\mathrm{CO}_{2}\right)$ was equal to $\left(\mathrm{CO}_{2}\right)_{\text {sat }}$. The $\left(\mathrm{CO}_{2}\right)$ associated with a $50 \%$ reduction in $a\left[\left(\mathrm{CO}_{2}\right)_{50 \%}\right]$ was also calculated.

\section{Expt 3: Effect of water status on light and} $\mathrm{CO}_{2}$ responses of $B$. papyrifera

Eight trees of $B$. papyrifera of similar size were selected for the experiment conducted on 12 and 13 Sept. 2005. Water was withheld from four randomly selected trees until the average predawn water potential $\left(\Psi_{\text {predawn }}\right)$ reached $\approx-2.5 \mathrm{MPa}$ measured psychrometrically (Oosterhuis and Wulleschleger, 1987). $\mathrm{A} / \mathrm{PPFD}$ and $\mathrm{A} /\left(\mathrm{CO}_{2}\right)$ response curves were generated for well-watered (WW; $\Psi_{\text {predawn }} \approx$ $-0.5 \mathrm{MPa}$ ) and water-deficit-stressed (WS; $\left.\Psi_{\text {predawn }} \approx-2.5 \mathrm{MPa}\right)$ B. papyrifera as described in Expts. 1 and 2.

\section{Experimental designs}

Expts. 1 and 2. The experimental design for $\mathrm{A} / \mathrm{PPFD}$ and $\mathrm{A} /\left(\mathrm{CO}_{2}\right)$ responses of four 


\begin{tabular}{|c|c|c|c|c|}
\hline \multirow[b]{2}{*}{ Parameters } & \multicolumn{4}{|c|}{ Light and $\mathrm{CO}_{2}$ response variables } \\
\hline & B. alleghaniensis & B. davurica & B. nigra Cully & B. papyrifera \\
\hline $\operatorname{PPFD}_{\text {comp }}\left(\mu \mathrm{mol} \cdot \mathrm{m}^{-2} \cdot \mathrm{s}^{-1}\right.$ photon $)$ & $17 \mathrm{NS}^{\mathrm{y}}$ & 22 NS & $21 \mathrm{NS}$ & $21 \mathrm{NS}$ \\
\hline PPFD $_{50 \%}\left(\mu \mathrm{mol} \cdot \mathrm{m}^{-2} \cdot \mathrm{s}^{-1}\right.$ photon $)$ & $185 \mathrm{ab}$ & 249 a & $206 \mathrm{ab}$ & $165 \mathrm{~b}$ \\
\hline Quantum efficiency, $\Phi$ & $0.049 \mathrm{NS}$ & $0.050 \mathrm{NS}$ & $0.066 \mathrm{NS}$ & $0.054 \mathrm{NS}$ \\
\hline $\operatorname{Amax}\left(\mu \mathrm{mol} \cdot \mathrm{m}^{-2} \cdot \mathrm{s}^{-1} \mathrm{CO}_{2}\right)$ & $11.7 \mathrm{~b}$ & $14.2 \mathrm{a}$ & $14.1 \mathrm{a}$ & $11.9 \mathrm{~b}$ \\
\hline Dark respiration, $R_{d}\left(\mu \mathrm{mol} \cdot \mathrm{m}^{-2} \cdot \mathrm{s}^{-1} \mathrm{CO}_{2}\right)$ & $0.9 \mathrm{NS}$ & $1.1 \mathrm{NS}$ & $1.3 \mathrm{NS}$ & $1.1 \mathrm{NS}$ \\
\hline \multicolumn{5}{|l|}{$\mathrm{CO}_{2}$ response variables ${ }^{\mathrm{x}}$} \\
\hline$\left(\mathrm{CO}_{2}\right)_{\text {comp }}(\mathrm{ppm})$ & $61 \mathrm{NS}$ & $57 \mathrm{NS}$ & $58 \mathrm{NS}$ & 55 NS \\
\hline$\left(\mathrm{CO}_{2}\right)_{50 \%}(\mathrm{ppm})$ & $368 \mathrm{~b}$ & $417 \mathrm{a}$ & $271 \mathrm{c}$ & $309 \mathrm{c}$ \\
\hline$\left(\mathrm{CO}_{2}\right)_{\mathrm{sat}}(\mathrm{ppm})$ & $1083 \mathrm{~b}$ & $1251 \mathrm{a}$ & $767 \mathrm{c}$ & $898 \mathrm{c}$ \\
\hline Carboxylation efficiency, $b$ & $0.0023 \mathrm{c}$ & $0.0020 \mathrm{~d}$ & $0.0033 \mathrm{a}$ & $0.0027 \mathrm{~b}$ \\
\hline Potential assimilation capacity, $a\left(\mu \mathrm{mol} \cdot \mathrm{m}^{-2} \cdot \mathrm{s}^{-1} \mathrm{CO}_{2}\right)$ & $24.6 \mathrm{~b}$ & $37.2 \mathrm{a}$ & $22.6 \mathrm{c}$ & $25.0 \mathrm{~b}$ \\
\hline Intercept on the ordinate, $c\left(\mu \mathrm{mol} \cdot \mathrm{m}^{-2} \cdot \mathrm{s}^{-1} \mathrm{CO}_{2}\right)$ & $-3.1 \mathrm{a}$ & $-3.9 \mathrm{c}$ & $-3.9 \mathrm{c}$ & $-3.5 \mathrm{~b}$ \\
\hline
\end{tabular}
$A=\left[\Phi \times P P F D+A \max -\sqrt{(\Phi \times P P F D+A \max )^{2}-4 \Phi \times P P F D \times k \times A \max }\right] /(2 k)-R_{d}$ generated for each plant.

${ }^{\mathrm{y}}$ Each number was the mean of six replicates. Means within a row followed by the same letter were not significantly different according to the protected least significant difference test at 0.05 level. Means followed by NS within a row were nonsignificant.

${ }^{\mathrm{x}}\left(\mathrm{CO}_{2}\right)_{\text {comp }},\left(\mathrm{CO}_{2}\right)_{50 \%}$, and $\left(\mathrm{CO}_{2}\right)_{\text {sat }}$ were calculated when A was equal to $0,50 \%$, and $90 \%$ of $a$ from the model $A=a\left(1-e^{-b C a}\right)+c$ generated for each plant.
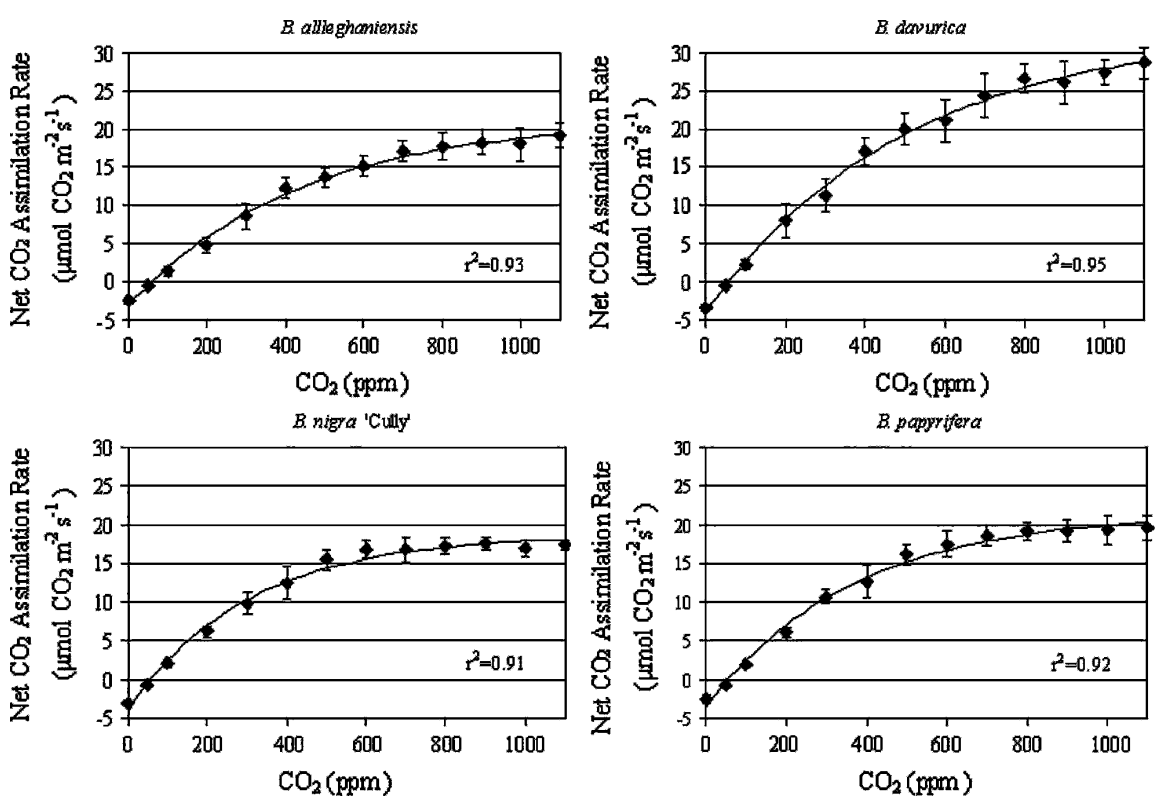

Fig. 2. Net $\mathrm{CO}_{2}$ assimilation rate (A) in response to varied ambient $\mathrm{CO}_{2}$ concentration (Ca) of four birch genotypes. The cuvette conditions were set at $25{ }^{\circ} \mathrm{C}, 70 \%$ relative humidity, and $1300 \mu \mathrm{mol} \cdot \mathrm{m}^{-2} \cdot \mathrm{s}^{-1}$ photon photosynthetic photon flux density. Diamond symbols are means of six plants. Vertical bars $( \pm \mathrm{SE})$ were shown if greater than the symbol size. Curves were predicted values from the following equations generated by SAS PROC NLIN from the measured data. $B$. alleghaniensis: $a=24.46 \times$ $\left(1-\mathrm{e}^{-0.00226 \mathrm{Ca}}\right)-3.08 ;$ B. davurica: $\mathrm{A}=36.91 \times\left(1-\mathrm{e}^{-0.00198 \mathrm{Ca}}\right)-3.89 ;$ B. nigra 'Cully': $\mathrm{A}=22.55 \times$ $\left(1-\mathrm{e}^{-0.00329 \mathrm{Ca}}\right)-3.85 ;$ B. papyrifera: $\mathrm{A}=25.07 \times\left(1-\mathrm{e}^{-0.00273 \mathrm{Ca}}\right)-3.50$.

birch genotypes was a completely randomized design with the genotype as the main factor and six replication trees per treatment. Data were subjected to SAS PROC NLIN procedure (SAS Institute, Cary, NC) to generate light and $\mathrm{CO}_{2}$ response equations for each genotype. The variables of light and $\mathrm{CO}_{2}$ response equation (A, $\Phi$, Amax, $\mathrm{R}_{\mathrm{d}}, a, b$, and $c$ ) and the calculated values [PPFD ${ }_{\text {comp, }}$, $\mathrm{PPFD}_{50 \%}, \mathrm{PPFD}_{\text {sat }}$, light-saturated A, $\left(\mathrm{CO}_{2}\right)_{\text {comp }}$, $\left(\mathrm{CO}_{2}\right)_{50 \%}$, and $\left(\mathrm{CO}_{2}\right)_{\text {sat }},\left(\mathrm{CO}_{2}\right)$-saturated $\left.\mathrm{A}\right]$ were subjected to analysis of variance to investigate difference among genotypes and means were separated with a protected least significant difference at $P \leq 0.05$.

Expt. 3. Data from A/PPFD and A/ $\left(\mathrm{CO}_{2}\right)$ responses of $B$. papyrifera were analyzed similarly like in Expts. 1 and 2, except with the plant water status as the main factor.

\section{Results and Discussion}

Expt. 1: A/PPFD response of four wellwatered birch genotypes. There was a close relationship between PPFD and A of the four birch genotypes $\left(r^{2}=0.97-0.99\right.$, Fig. 1$)$. In the four birch genotypes, net $\mathrm{CO}_{2}$ assimilation increased linearly at low PPFD, where it was limited by electron transport rate, and gradually reached a plateau where A would be limited by Rubisco capacity (Ogren, 1993). Detectable decrease in assimilation at high PPFD, an indication of photoinhibition, was not observed in any of the four genotypes for the PPFD range studied ( 0 to $2000 \mu \mathrm{mol} \cdot \mathrm{m}^{-2} \cdot \mathrm{s}^{-1}$ photon). Therefore, all data were used for analysis of the relationship between PPFD and A.

The four birch genotypes reached PPFD $_{\text {comp }}$ at $\approx 20 \mu \mathrm{mol} \cdot \mathrm{m}^{-2} \cdot \mathrm{s}^{-1}$ photon (Table 1). The PPFD ${ }_{\text {comp }}$ was similar for the four genotypes. Net $\mathrm{CO}_{2}$ assimilation increased rapidly as PPFD was increased from 0 to $\approx 200 \mu \mathrm{mol} \cdot \mathrm{m}^{-2} \cdot \mathrm{s}^{-1}$ photon $(\approx 10 \%$ of full sunlight), where four birch genotypes reached

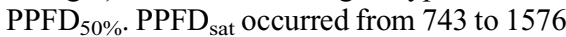
$\mu \mathrm{mol} \cdot \mathrm{m}^{-2} \cdot \mathrm{s}^{-1}$ photon (Fig. 1; Table 1), which is $\approx 30 \%$ to $70 \%$ of full sunlight. PPFD $_{50 \%}$ and $\mathrm{PPFD}_{\text {sat }}$ were significantly different among the four birch genotypes. PPFD $50 \%$ and $\mathrm{PPFD}_{\mathrm{sat}}$ of Betula davurica were $51 \%$ and $112 \%$ greater than $B$. papyrifera, respectively.

There were no differences in the photosynthetic quantum efficiencies $(\Phi)$ among the four genotypes (Table 1), which indicated that the four birch genotypes use light in photochemistry at similar efficiency at low irradiance when Rubisco is saturating and light is the limiting factor of photosynthesis.

The light response variables of B. papyrifera were similar to a previous study $(\mathrm{Gu}$ et al., 2003). No difference was detected for $\mathrm{R}_{\mathrm{d}}$ among the genotypes, which ranged from $0.9 \mu \mathrm{mol} \cdot \mathrm{m}^{-2} \cdot \mathrm{s}^{-1} \mathrm{CO}_{2}$ in $B$. alleghaniensis to $1.3 \mu \mathrm{mol} \cdot \mathrm{m}^{-2} \cdot \mathrm{s}^{-1} \mathrm{CO}_{2}$ in $B$. nigra 'Cully'. The birch genotypes differed in light-saturated A and Amax (Table 1). Betula davurica and B. nigra 'Cully', which had greater $\mathrm{PPFD}_{50 \%}$ and PPFD $_{\text {sat }}$, had greater Amax and lightsaturated A than $B$. alleghaniensis and 

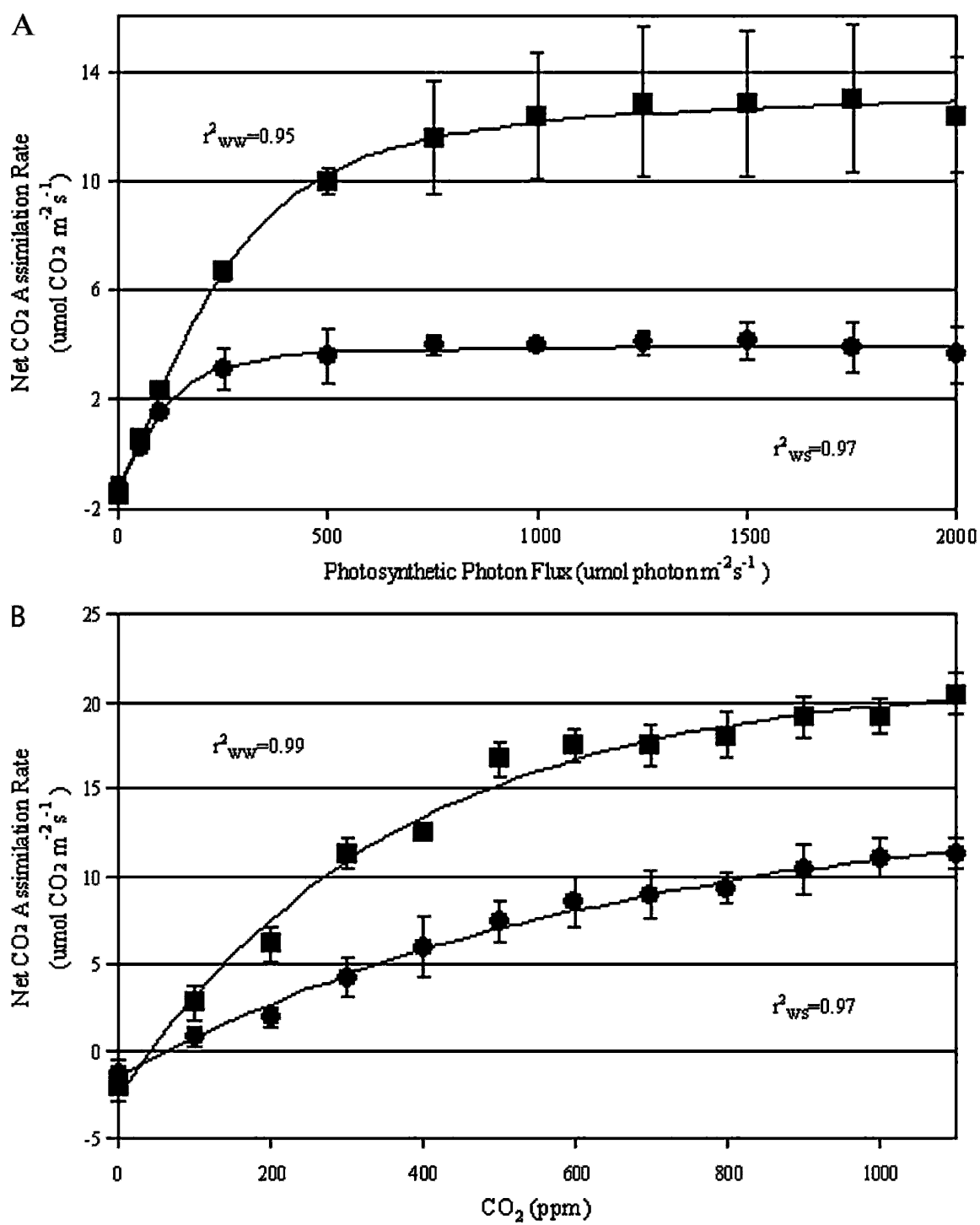

Fig. 3. Net $\mathrm{CO}_{2}$ assimilation (A) in response to (a) varied photosynthetic photon flux density (PPFD) and (B) ambient $\mathrm{CO}_{2}$ concentrations (Ca). The cuvette condition in (A) were set at $25{ }^{\circ} \mathrm{C}, 70 \%$ relative humidity, and $350 \mathrm{ppm}\left(\mathrm{CO}_{2}\right)$. The cuvette conditions in $(\mathrm{Bb})$ were set at $25^{\circ} \mathrm{C}, 70 \%$ relative humidity, and $1300 \mu \mathrm{mol} \cdot \mathrm{m}^{-2} \cdot \mathrm{s}^{-1}$ photon PPFD of well-watered (WW; - ) and water-deficit-stressed (WS; $\bullet$ ) B. papyrifera. Data represented means of four plants. Vertical bars $( \pm \mathrm{SE})$ were shown if greater than the symbol size. Curves were predicted values from the following equations generated by SAS PROC NLIN from the measured data. Well-watered B. papyrifera: $\mathrm{A}=[0.039 \times \mathrm{PPFD}+$ $\left.14.91-\sqrt{(0.039 \times P P F D+14.91)^{2}-1.90 \times P P F D}\right] / 1.62-1.42 ;$ and $\mathrm{A}=23.93 \times\left(1-\mathrm{e}^{-0.00275 \mathrm{Ca} a}\right)-$ 2.63. Water-deficit-stressed $B$. papyrifera: $\mathrm{A}=[0.031 \times \mathrm{PPFD}+5.26-$ $\left.\sqrt{(0.031 \times P P F D+5.26)^{2}-0.55 \times P P F D}\right] / 1.67-1.21 ;$ and $\mathrm{A}=15.99 \times\left(1-\mathrm{e}^{-0.00153 \mathrm{Ca}}\right)-1.57$.

B. papyrifera. Betula davurica and $B$. nigra 'Cully' are from warmer origins than $B$. alleghaniensis and B. papyrifera, which could have affected their light response. Amax of B. papyrifera $\left(11.9 \mu \mathrm{mol} \cdot \mathrm{m}^{-2} \cdot \mathrm{s}^{-1} \mathrm{CO}_{2}\right)$ was similar to a previous report (Jurik et al., 1988). Amax of B. davurica and B. nigra 'Cully' (14.2 and $14.1 \mu \mathrm{mol} \cdot \mathrm{m}^{-2} \cdot \mathrm{s}^{-1} \mathrm{CO}_{2}$, respectively) was $\approx 20 \%$ higher than those of $B$. alleghaniensis and $B$. papyrifera. Higher $P_{P F D} D_{\text {sat }}$ and Amax in $B$. davurica and B. nigra 'Cully' indicates their ability to convert a greater portion of the absorbed light energy to photochemistry and may lower the amount of excess energy needed to be dissipated by plants, as indicated in a similar study on Illicium (Griffin et al., 2004a). The greater ability observed in $B$. davurica and $B$. nigra 'Cully' to make use of sunlight than $B$. alleghaniensis and $B$. papyrifera might enable them to grow faster under full sun situations in the landscape and was consistent with field evaluation at Fayetteville, AR (Gu et al., 2007). On the other hand, the fact that $B$. alleghaniensis and B. papyrifera reached $\mathrm{PPFD}_{\mathrm{sat}}$ and Amax sooner indicated that they are more suitable for landscape situations with lower light levels than $B$. davurica and B. nigra 'Cully'.

Light compensation point ( $\mathrm{PPFD}_{\text {comp }}$ ), $\mathrm{R}_{\mathrm{d}}$, and Amax are significantly greater in high-light-acclimated plants compared with low-light-acclimated plants (Lambers et al.,
1998). This experiment did not find significant differences in $\mathrm{PPFD}_{\text {comp }}$ or $\mathrm{R}_{\mathrm{d}}$ among four birch genotypes. However, $\mathrm{PPFD}_{\text {sat }}$ of $B$. davurica and $B$. nigra 'Cully' were significantly higher than $B$. alleghaniensis or $B$. papyrifera, which might indicate their lower shade-tolerance level. Although it was found to be the most shade-intolerant compared with other forest species (Kobe and Coates, 1997), $B$. papyrifera might not be the most shadeintolerant among Betula species based on the A/PPFD response under greenhouse conditions.

The value of curvature factor $(\mathrm{k})$ determines the photosynthetic efficiency in the intermediate light range above the linear region (Ogren, 1993). The position of the breaking points between the two limits (electron transport rate and Rubisco capacity) determines $\mathrm{k}$, and the Rubisco limitation/ light saturation setting at low light levels could result in a higher value of $\mathrm{k}$ (Ogren, 1993). Betula papyrifera had a significantly greater $\mathrm{k}$ value than the other genotypes (Table 1), which was consistent with the observation that $B$. papyrifera reached Rubisco limitation/light saturation faster (as indicated by PPFD $_{\text {sat }}$ ) than the other three genotypes.

Expt 2: $\mathrm{A} /\left(\mathrm{CO}_{2}\right)$ responses of four wellwatered birch genotypes. At $1300 \mu \mathrm{mol} \cdot \mathrm{m}^{-2} \cdot \mathrm{s}^{-1}$ photon PPFD, the net $\mathrm{CO}_{2}$ assimilation of four birch genotypes increased rapidly to a value of 15 to $20 \mu \mathrm{mol} \cdot \mathrm{m}^{-2} \cdot \mathrm{s}^{-1} \mathrm{CO}_{2}$ with the cuvette $\left(\mathrm{CO}_{2}\right)$ elevated to $700 \mathrm{ppm}$ (Fig. 2). The $\mathrm{A} /\left(\mathrm{CO}_{2}\right)$ responses indicated that initial linear regions at low $\left(\mathrm{CO}_{2}\right)$ were Rubisco-saturated and $\mathrm{CO}_{2}$-limited, which changed to $\mathrm{CO}_{2}$ saturated and Rubisco-limited regions at high $\left(\mathrm{CO}_{2}\right)$ (Farquhar and Sharkey, 1982).

The $\left(\mathrm{CO}_{2}\right)_{\text {comp, }}$ which was not significantly different among the four genotypes, was reached at $\approx 60 \mathrm{ppm}$ (Table 1 ). This was similar to a previous report on $B$. pendula under $600 \mu \mathrm{mol} \cdot \mathrm{m}^{-2} \cdot \mathrm{s}^{-1}$ photon PPFD (Pettersson and McDonald, 1992). The $\left(\mathrm{CO}_{2}\right)_{50 \%}$ was significantly different among the four birch genotypes. Betula nigra 'Cully' and $B$. papyrifera had the lowest $\left(\mathrm{CO}_{2}\right)_{50 \%}, 271 \mathrm{ppm}$ and $309 \mathrm{ppm}$, respectively. Betula davurica had the greatest $\left(\mathrm{CO}_{2}\right)_{50 \%}$ of $417 \mathrm{ppm}$. At $1300 \mu \mathrm{mol} \cdot \mathrm{m}^{-2} \cdot \mathrm{s}^{-1}$ photon PPFD, B. davurica had the greatest $\left(\mathrm{CO}_{2}\right)_{\text {sat }}$, which was $63 \%$ higher than B. nigra 'Cully' (Table 1).

The carboxylation efficiency, $b$, was negatively correlated with $\left(\mathrm{CO}_{2}\right)_{50 \%}$ and $\left(\mathrm{CO}_{2}\right)_{\text {sat }}$ in four birch genotypes (Table 1). Betula nigra 'Cully', which had the greatest value of $b(0.0033)$ and reached the $\mathrm{CO}_{2}$-saturated stage faster than the other three genotypes, had the lowest $\left(\mathrm{CO}_{2}\right)_{50 \%}$ and $\left(\mathrm{CO}_{2}\right)_{\text {sat }}$. It also had the lowest $a$ (potential assimilation capacity) and $\mathrm{CO}_{2}$-saturated $\mathrm{A}$ (22.6 and $18.8 \mu \mathrm{mol} \mathrm{CO}_{2} \mathrm{~m}^{-2} \cdot \mathrm{s}^{-1}$, respectively). By contrast, $B$. davurica, which had the lowest value of $b(0.0020)$ and reached $\mathrm{CO}_{2}$-saturated stage slower, had the greatest $\left(\mathrm{CO}_{2}\right)_{50 \%}$ and $\left(\mathrm{CO}_{2}\right)_{\text {sat }}$. Promotion of assimilation by increasing $\left(\mathrm{CO}_{2}\right)$ would be more detectable on $B$. davurica relative to the other genotypes. The greatest $\left(\mathrm{CO}_{2}\right)_{50 \%}(417 \mu \mathrm{mol} \mathrm{CO}$ $\left.\mathrm{m}^{-2} \cdot \mathrm{s}^{-1}\right)$ and $\left(\mathrm{CO}_{2}\right)_{\text {sat }}\left(1251 \mu \mathrm{mol} \cdot \mathrm{m}^{-2} \cdot \mathrm{s}^{-1}\right.$ $\mathrm{CO}_{2}$ ) associated with $B$. davurica allowed it 
to continue $\mathrm{CO}_{2}$ assimilation at high $\left(\mathrm{CO}_{2}\right)$, whereas the other three birch genotypes could not. Betula davurica had the greatest $a\left(37.2 \mu \mathrm{mol} \cdot \mathrm{m}^{-2} \cdot \mathrm{s}^{-1} \mathrm{CO}_{2}\right)$. Betula davurica, which had the greater Amax in the light response experiment, had the $\mathrm{CO}_{2}$ assimilation $60 \%$ greater than the other three genotypes at $\left(\mathrm{CO}_{2}\right)_{\text {sat }}$. On the contrary, Betula nigra 'Cully', which also had the greatest Amax in light response, had the least assimilation at $\left(\mathrm{CO}_{2}\right)_{\text {sat }}$.

Birch selections such as $B$. nigra 'Cully' are usually vegetatively propagated in controlled environments before planted outside, which made $\mathrm{CO}_{2}$ enrichment possible during the early stage of propagation. This might also be applicable to the other vegetatively propagated birch selections such as $B \times$ 'Royal Frost', $B$. nigra 'BNMTF', $B$. pendula 'Laciniata', and B. platyphylla 'Fargo' and selections of the other woody ornamental genera.

Expt. 3: Light and $\left(\mathrm{CO}_{2}\right)$ responses [A/ PPFD and $\left.\mathrm{A} /\left(\mathrm{CO}_{2}\right)\right]$ of well-watered and water-deficit-stressed $B$. papyrifera. Wellwatered plants had significantly greater A than WS plants under PPFD from 100 to 2000 $\mu \mathrm{mol} \cdot \mathrm{m}^{-2} \cdot \mathrm{s}^{-1}$ photon (Fig. 3A). Amax and light-saturated $\mathrm{A}$ of $\mathrm{WW}$ plants (15.4 and $14.0 \mu \mathrm{mol} \cdot \mathrm{m}^{-2} \cdot \mathrm{s}^{-1} \quad \mathrm{CO}_{2}$ ) were $\approx 3$ times greater than WS plants $(5.3$ and $4.0 \mu \mathrm{mol}$ $\mathrm{CO}_{2} \mathrm{~m}^{-2} \cdot \mathrm{s}^{-1}$; Table 2). Water-deficit stress did not affect PPFD $_{\text {comp. }}$ PPFD $_{50 \%}$ and $\mathrm{PPFD}_{\text {sat }}$ of WW plants and values were approximately twice as high as the values for WS plants. Calculated $\Phi$ was greater in WW plants than WS plants. There was no significant effect on $R_{d}$ or $k$ between WW and WS plants. Therefore, although WW plants

Table 2. Light response and $\mathrm{CO}_{2}$ response variables of well-watered and water-deficit-stressed B. papyrifera.

\begin{tabular}{|c|c|c|c|}
\hline \multirow[b]{2}{*}{ Parameters } & \multicolumn{2}{|c|}{ Light and $\mathrm{CO}_{2}$ response variables } & \multirow[b]{2}{*}{$\begin{array}{c}\text { Significance } \\
\text { of F-test }(0.05)^{\mathrm{z}} \\
\end{array}$} \\
\hline & Well-watered & $\begin{array}{l}\text { Water-deficit- } \\
\text { stressed }\end{array}$ & \\
\hline \multicolumn{4}{|l|}{ Light response variables $^{\mathrm{y}}$} \\
\hline $\operatorname{PPFD}_{\text {comp }}\left(\mu \mathrm{mol} \cdot \mathrm{m}^{-2} \cdot \mathrm{s}^{-1}\right.$ photon $)$ & 40 & 37 & NS \\
\hline PPFD $_{50 \%}\left(\mu \mathrm{mol} \cdot \mathrm{m}^{-2} \cdot \mathrm{s}^{-1}\right.$ photon $)$ & 268 & 133 & sig. \\
\hline $\operatorname{PPFD}_{\text {sat }}\left(\mu \mathrm{mol} \cdot \mathrm{m}^{-2} \cdot \mathrm{s}^{-1}\right.$ photon $)$ & 752 & 366 & sig. \\
\hline Quantum efficiency, $\Phi$ & 0.040 & 0.028 & sig. \\
\hline $\operatorname{Amax}\left(\mu \mathrm{mol} \cdot \mathrm{m}^{-2} \cdot \mathrm{s}^{-1}\right)$ & 15.4 & 5.3 & sig. \\
\hline Dark respiration, $\mathrm{R}_{\mathrm{d}}\left(\mu \mathrm{mol} \cdot \mathrm{m}^{-2} \cdot \mathrm{s}^{-1} \mathrm{CO}_{2}\right)$ & 1.4 & 1.2 & NS \\
\hline $\begin{array}{l}\text { Light-saturated net } \mathrm{CO}_{2} \\
\quad \text { assimilation }\left(\mu \mathrm{mol} \cdot \mathrm{m}^{-2} \cdot \mathrm{s}^{-1} \mathrm{CO}_{2}\right)\end{array}$ & 14.0 & 4.0 & sig. \\
\hline Curvature factor, $\mathrm{k}$ & 0.802 & 0.779 & NS \\
\hline \multicolumn{4}{|l|}{$\mathrm{CO}_{2}$ response variables ${ }^{\mathrm{x}}$} \\
\hline$\left(\mathrm{CO}_{2}\right)_{\text {comp }}(\mathrm{ppm})$ & 70 & 43 & NS \\
\hline$\left(\mathrm{CO}_{2}\right)_{50 \%}(\mathrm{ppm})$ & 546 & 292 & sig. \\
\hline$\left(\mathrm{CO}_{2}\right)_{\text {sat }}(\mathrm{ppm})$ & 871 & 1651 & sig. \\
\hline Carboxylation efficiency, $b$ & 0.0028 & 0.0015 & sig. \\
\hline Potential assimilation & 230 & 164 & $\operatorname{sig}$ \\
\hline Intercept on the ordinate, $c\left(\mu \mathrm{mol} \cdot \mathrm{m}^{-2} \cdot \mathrm{s}^{-1} \mathrm{CO}_{2}\right)$ & $\begin{array}{r}2.7 \\
2.7\end{array}$ & $\begin{array}{r}1.4 \\
1.6\end{array}$ & sig. \\
\hline $\begin{array}{l}\mathrm{CO}_{2} \text {-saturated net } \mathrm{CO}_{2} \\
\quad \text { assimilation }\left(\mu \mathrm{mol} \cdot \mathrm{m}^{-2} \cdot \mathrm{s}^{-1} \mathrm{CO}_{2}\right)\end{array}$ & 21.2 & 14.8 & sig. \\
\hline
\end{tabular}

${ }^{\mathrm{z}}$ The results of $\mathrm{F}$-test of light and $\mathrm{CO}_{2}$ response variables were presented as not significant indicated by NS or significant indicated by sig. at 0.05 confidence interval level.

${ }^{y} \mathrm{PPFD}_{\text {comp }}, \mathrm{PPFD}_{50 \%}$, and $\mathrm{PPFD}_{\text {sat }}$ were calculated when assimilation was equal to $0,50 \%$, and $90 \%$ of $\mathrm{Amax}$ from the model $A=\left[\Phi \times P P F D+A \max -\sqrt{(\Phi \times P P F D+A \max )^{2}-4 \Phi \times P P F D \times k \times A \max }\right] /(2 k)-R_{d}$ generated for each plant.

${ }^{x}\left(\mathrm{CO}_{2}\right)_{\text {comp }},\left(\mathrm{CO}_{2}\right)_{50 \%}$, and $\left(\mathrm{CO}_{2}\right)_{\text {sat }}$ were calculated when assimilation was equal to $0,50 \%$, and $90 \%$ of $a$ from the model $A=a\left(1-e^{b C a}\right)+c$ generated for each plant.
Photosynthetic activity was significantly affected by water deficit in B. papyrifera as indicated by less assimilation in both light and $\mathrm{CO}_{2}$ responses (Table 2). In light response, water stress decreased $\Phi$ (quantum efficiency) by $30 \%$ and Amax by $66 \%$, and in $\mathrm{CO}_{2}$ response, water stress decreased $b$ (carboxylation efficiency) by $48 \%$ and decreased $a$ by $31 \%$, which both indicated nonstomatal limitation of assimilation under water stress. Reduction of photosynthesis by water stress was observed in field-grown soybean; however, quantum efficiency and carboxylation efficiency were unaffected by water stress (Sullivan and Teramura, 1990). The discrepancy between the two studies might result from different levels of water stress. Stomatal closure is the dominant limitation to photosynthesis at mild to moderate water stress, and decreased Rubisco content becomes the dominant limitation on photosynthesis at severe water stress (Flexas and Medrano, 2002), which may have caused decreased quantum efficiency and carboxylation efficiency in the current study $\left(\Psi_{\text {predawn }} \approx-2.5\right.$ $\mathrm{MPa}) . \mathrm{CO}_{2}$ enrichment was found to significantly increase water use efficiency in rice exposed to water stress (Baker et al., 1997). Less reduction in photosynthesis of $B$. papyrifera under a high level of $\left(\mathrm{CO}_{2}\right)$ compared with under a high light level agreed with Baker et al.'s finding that increased $\left(\mathrm{CO}_{2}\right)$ might be able to alleviate water stress or improve water use efficiency under ambient light level.

Based on our results, $\mathrm{k}, \mathrm{PPFD}_{\mathrm{sat}}$ and Amax in photosynthesis light response appeared to be good indicators of shade tolerance of birch genotypes, and $\mathrm{k}$ is unaffected by water-deficit stress, whereas PPFD $_{\text {sat }}$ and Amax were reduced by water-deficit stress. These values could serve as a basis for recommending birch genotypes for landscapes with various light conditions in the landscape. Almost all birch species are considered shade-intolerant, and special attention might need to be paid to their shade tolerance in landscape situations. Based on our results, $B$. davurica had the highest Amax in both light and $\mathrm{CO}_{2}$ responses among the four birch genotypes examined under greenhouse conditions. Despite its northern origin of northeastern China, active responses of $B$. davurica to a high light level and $\left(\mathrm{CO}_{2}\right)$ in the greenhouse were confirmed by field performance at two locations in Arkansas representing U.S. Department of Agriculture cold hardiness Zone 7 and 8 (Gu et al., 2007). $\mathrm{CO}_{2}$ enrichment could potentially increase plant growth of birch genotypes in a controlled environment, and it might be important to manage water status to maximize the benefit of $\mathrm{CO}_{2}$ enrichment.

\section{Literature Cited}

Atkinson, M.D. 1992. Betula pendula Roth (B. verrucosa Ehrh.) and B. pubescens Ehrh. J. Ecol. 80:837-870.

Baker, J.T., L.H. Allen, Jr., K.J. Boote, and N.B. Pickering. 1997. Rice responses to drought under carbon dioxide enrichment. 2. Photosynthesis 
and evapotranspiration. Glob. Change Biol. 3:129-138.

Edwards, D.R., P.A. Jolliffe, and D.L. Ehret. 2004 Carbon status of $\mathrm{CO}_{2}$-enriched tomato plants under commercial greenhouse conditions. In: A.P. Papadopoulos, M.M. Peet, A.F. AbouHadid, G. Giacomelli, and A. Gosselin (eds.). Protected cultivation 2002: In search of structures, systems and plant materials for sustainable greenhouse production-Proceedings of the XXVI International Horticultural Congress. Acta Hort. 633:279-286.

Farquhar, G.D. and T.D. Sharkey. 1982. Stomatal conductance and photosynthesis. Ann. Rev. Plant. Physiol. 33:317-345.

Flexas, J. and H. Medrano. 2002. Drought-inhibition of photosynthesis in C3 plants: Stomatal and non-stomatal limitations revisited. Ann. Bot. (Lond.) 89:183-189.

Gao, H., S. Wang, and J. Wang. 2004. Fruit protected cultivation in China. In: A.P. Papadopoulos, M.M. Peet, A.F. Abou-Hadid, G. Giacomelli, and A. Gosselin (eds.). Protected cultivation 2002: In search of structures, systems and plant materials for sustainable greenhouse production-Proceedings of the XXVI international horticultural congress. Acta Hort. 633:59-66.

Griffin, J.J., T.G. Ranney, and D.M. Pharr. 2004a. Photosynthesis, chlorophyll fluorescence, and carbohydrate content of Illicium taxa grown under varied irradiance. J. Amer. Soc. Hort. Sci. 129:46-53.

Griffin, J.J., T.G. Ranney, and D.M. Pharr. 2004b. Heat and drought influence photosynthesis, water relations, and soluble carbohydrates of two ecotypes of redbud (Cercis canadensis). J. Amer. Soc. Hort. Sci. 129:497-502.
Gu, M., J.A. Robbins, and C.R. Rom. 2007. Early landscape performance of twenty field-grown birch genotypes at two locations in Arkansas and response to irrigation. Arboriculture \& Urban Forestry 33:275-282.

Gu, M., C.R. Rom, and J.A. Robbins. 2003. Leaf gas exchange response to photon flux density of six birch taxa. Ark. Agr. Exp. Sta. Res. Series 506:17-19.

Jurik, T.W., J.A. Weber, and D.M. Gates. 1988. Effects of temperature and light on photosynthesis of dominant species of a northern hardwood forest. Bot. Gaz. 149:203-208.

Kobe, R.K. and K.D. Coates. 1997. Models of sapling mortality as a function of growth to characterize interspecific variation in shade tolerance of eight tree species of northwestern British Columbia. Can. J. For. Res. 27:227-236.

Krussmann, G. 1984. Manual of cultivated broadleaved trees and shrubs. 1st ed. Timber Press, Beaverton, OR.

Lambers, H., F.S. Chapin, III, and T.L. Pons. 1998. Photosynthesis, respiration, and long-distance transport, p. 10-125. In: H. Lambers, F.S. Chapin III, and T.L. Pons (eds.). Plant physiological ecology. Springer-Verlag, New York.

Leverenz, J.W. 1987. Chlorophyll content and the light response curve of shade-adapted conifer needles. Physiol. Plant. 71:20-29.

Makino, A. and T. Mae. 1999. Photosynthesis and plant growth at elevated levels of $\mathrm{CO}_{2}$. Plant Cell Physiol. 40:999-1006.

Ogren, E. 1993. Convexity of the photosynthetic light-response curve in relation to intensity and direction of light during growth. Plant Physiol. 101:1013-1019.

O’Hanlon-Manners, D.L. and P.M. Kotanen. 2004. Evidence that fungal pathogens inhibit recruit- ment of a shade-intolerant tree, white birch (Betula papyrifera), in understory habitats. Oecologia 140:650-653.

Oosterhuis, D.M. and S.D. Wulleschleger. 1987. Osmotic adjustment in cotton (Gossypium hirsutum $\mathrm{L}$.) leaves and roots in response to water stress. Plant Physiol. 84:1154-1157.

Peng, S. and D.R. Krieg. 1992. Gas exchange traits and their relationship to water use efficiency of grain sorghum. Crop Sci. 32:386-391.

Pettersson, R. and A.J.S. McDonald. 1992. Effects of elevated carbon dioxide concentration on photosynthesis and growth of small birch plants (Betula pendula Roth.) at optimal nutrition. Plant Cell Environ. 15:911-919.

Reid, C.D. and E.L. Fiscus. 1998. Effects of elevated $\left[\mathrm{CO}_{2}\right]$ and/or ozone on limitations to $\mathrm{CO}_{2}$ assimilation in soybean (Glycine max). J. Expt. Bot. 49:885-895.

Sage, R.F. 1994. Acclimation of photosynthesis to increasing atmospheric $\mathrm{CO}_{2}$ : The gas exchange perspective. Photosynth. Res. 39:351-368.

Sullivan, J.H. and A.H. Teramura. 1990. Field study of the interaction between solar ultraviolet-B radiation and drought on photosynthesis and growth in soybean. Plant Physiol. 92:141-146.

Wei, M., Y. Xing, X. Wang, and H. Ma. 2004. $\mathrm{CO}_{2}$ environment in solar greenhouse in Northern China and effects of $\mathrm{CO}_{2}$ enrichment on photosynthetic rate and dry matter production of cucumber. In: A.P. Papadopoulos, M.M. Peet, A.F. Abou-Hadid, G. Giacomelli, and A. Gosselin (eds.). Protected cultivation 2002: In search of structures, systems and plant materials for sustainable greenhouse productionProceedings of the XXVI International Horticultural Congress. Acta Hort. 633:115120 . 